\title{
Impact of Nanoscale Topography on Genomics and Proteomics of Adherent Bacteria
}

\author{
Loris Rizzello, ${ }^{\dagger}$ Barbara Sorce, ${ }^{\dagger}$ Stefania Sabella, Giuseppe Vecchio, Antonio Galeone, Virgilio Brunetti, \\ Roberto Cingolani, and Pier Paolo Pompa*
}

Italian Institute of Technology, Center for Bio-Molecular Nanotechnology, Via Barsanti-73010 Arnesano, Lecce, Italy. ${ }^{\dagger}$ These authors contributed equally to this work.

M ost implantable medical devices, such as intravascular catheters, ${ }^{1}$ pacemakers, ${ }^{2}$ ventricular devices, ${ }^{3}$ voice prostheses, ${ }^{4}$ and dental ${ }^{5}$ and orthopedic implants, ${ }^{6}$ are prone to infections caused by microorganisms that first adhere to the devices surface and then start to colonize and form hazardous biofilms. ${ }^{7-9}$ The development of innovative engineered biomaterials is thus a fundamental issue that still requires extensive investigations, especially from a multidisciplinary point of view. In this frame, there is a growing recognition that nanostructured substrates, along with their specific physicochemical properties, can regulate the responses of biological entities. ${ }^{10,11}$ In this respect, the central question is the understanding of the complex molecular mechanisms occurring at the interface between nanostructures and living matter, that may lead to a rationale design of biomaterials addressing tailored biological reactions. ${ }^{12}$ Nanotechnologyderived solutions for controlling such responses may come from biology itself, ${ }^{10}$ possibly allowing the realization of smart engineered surfaces with active biological functionality. In this work, we studied how highly controlled nanostructured substrates may impact the proteomic profile of adherent bacteria and influence the expression of some regulatory and structural genes. In previous studies, bacteria were typically considered as inert colloidal microparticles, ${ }^{13-15}$ and the surface characteristics (such as roughness, wettability, hydrophilicity, charge, etc.) of both bacteria and inorganic/engineered surfaces were investigated as a function of the adhesion events at the interface. ${ }^{16-24}$ However, concerning the role of nanoroughness on bacteria adhesion, controversial opinions were reported; in particular, some studies
ABSTRACT Bacterial adhesion onto inorganic/nanoengineered surfaces is a key issue in biotechnology and medicine, because it is one of the first necessary steps to determine a general pathogenic event. Understanding the molecular mechanisms of bacteria-surface interaction represents a milestone for planning a new generation of devices with unanimously certified antibacterial characteristics. Here, we show how highly controlled nanostructured substrates impact the bacterial behavior in terms of morphological, genomic, and proteomic response. We observed by atomic force microscopy (AFM) and scanning electron microscopy (SEM) that type-1 fimbriae typically disappear in Escherichia coli adherent onto nanostructured substrates, as opposed to bacteria onto reference glass or flat gold surfaces. A genetic variation of the fimbrial operon regulation was consistently identified by real time qPCR in bacteria interacting with the nanorough substrates. To gain a deeper insight into the molecular basis of the interaction mechanisms, we explored the entire proteomic profile of $E$. coli by 2D-DIGE, finding significant changes in the bacteria adherent onto the nanorough substrates, such as regulations of proteins involved in stress processes and defense mechanisms. We thus demonstrated that a pure physical stimulus, that is, a nanoscale variation of surface topography, may play per se a significant role in determining the morphological, genetic, and proteomic profile of bacteria. These data suggest that in depth investigations of the molecular processes of microorganisms adhering to surfaces are of great importance for the design of innovative biomaterials with active biological functionalities.

KEYWORDS: nanotopography $\cdot$ Escherichia coli $\cdot$ bacterial adhesion $\cdot$ fimbriae proteomics

revealed that an increase in surface roughness may promote bacterial adhesion, 25,26 while other researchers recently showed an opposite trend. ${ }^{27}$ Moreover, the understanding of the "biological" mechanisms regulating the bacterial response to micro/nano topography still remains a challenge. ${ }^{24}$ In this frame, we used a multidisciplinary approach, which deems bacteria as active biological systems, to analyze the bacteria-nanostructured substrates interaction. Bacteria, in fact, are "naturally programmed" to obey biological rules, responding, for instance, to several stimuli by morphological adaptation and variation. They can change protein composition of the cell wall

and membrane, ${ }^{28}$ can secrete proteins by $\odot 2011$ American Chemical Society
* Address correspondence to pierpaolo.pompa@iit.it.

Received for review October 8, 2010 and accepted February 11, 2011.

Published online February 23, 2011 $10.1021 / \mathrm{nn} 102692 \mathrm{~m}$ 


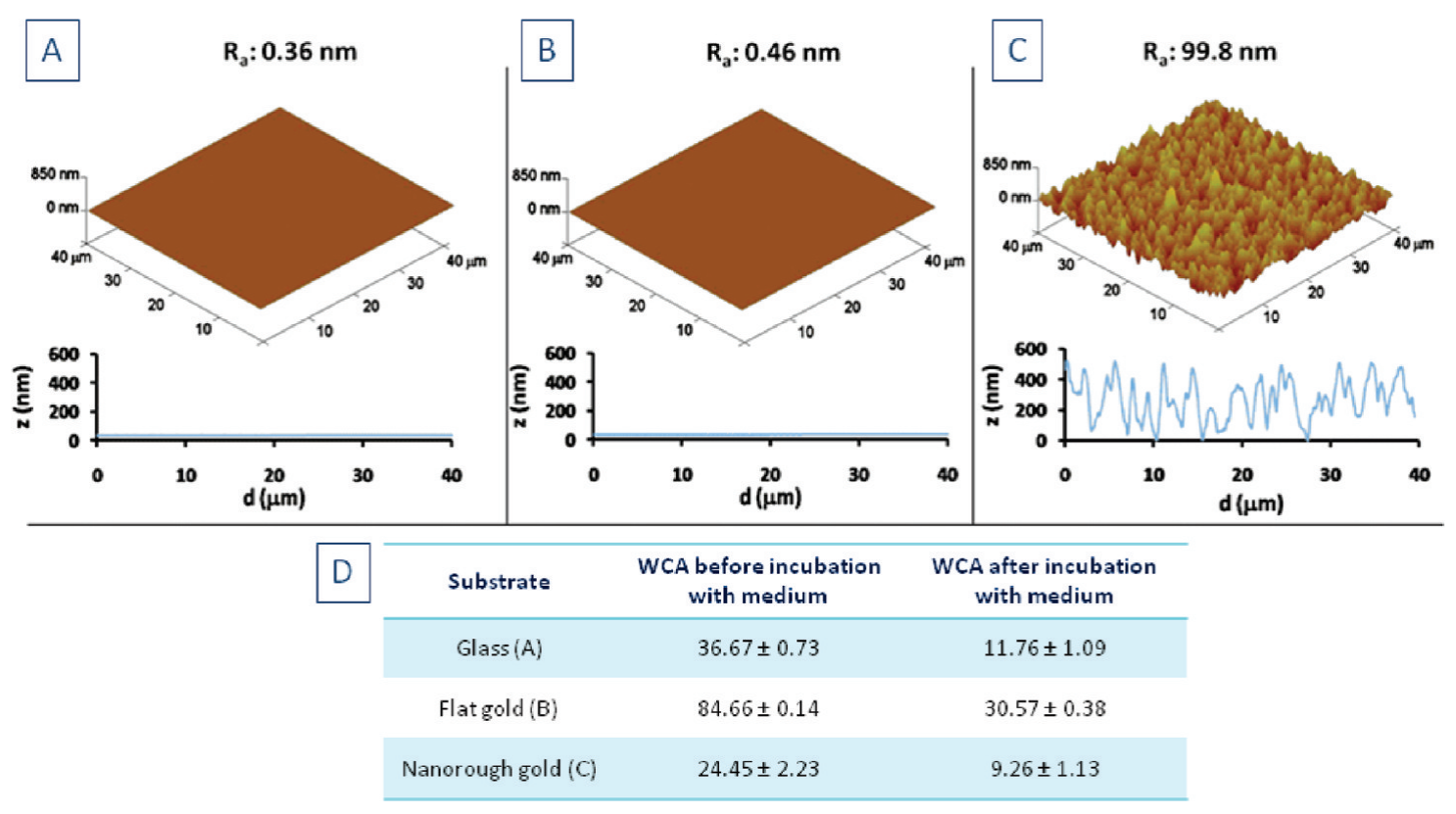

Figure 1. AFM analyses of glass (A), flat (B), and nanorough (C) gold substrates used for bacterial growth. $R_{\mathrm{a}}$ indicates the mean surface roughness, calculated on $40 \times 40 \mu \mathrm{m}^{2}$ regions. On the bottom of each substrate, representative line profiles are reported. (D) Surface wettability characterization of the substrates before and after incubation with the bacteria culture medium.

multiple pathways ${ }^{29}$ or the extracellular polymeric substance (EPS), ${ }^{30}$ or produce anchoring arms such as fimbriae. ${ }^{31}$ Specifically, we analyzed the effects that surface nanotopography exerts over the adhesion of the model system Escherichia coli, by carrying out morphological investigations along with genetic and proteomic assays. We fabricated flat and nanorough gold substrates using an electroless plating technique, namely spontaneous galvanic displacement reaction (SGDR). SGDR allows the achievement of tunable and controllable levels of surface nanoroughness, and has been exploited for several applications, such as synthesis of porous nanoparticles, ${ }^{32,33}$ catalysis, $^{34}$ patterning of hydrophobic/hydrophilic surfaces, ${ }^{35}$ fabrication of plasmonic substrates, ${ }^{36}$ and patterning of neurons. ${ }^{37}$ We grew E. coli on various gold substrates presenting different surface nanoroughness, and on glass and flat gold substrates, used as a reference. We investigated the potential changes in E. coli morphology through AFM and SEM inspections, detecting a significant difference in the bacteria grown over the nanorough surfaces, namely the absence of type-1 fimbriae. Real time qPCR (RT-qPCR) assays confirmed a nanotopography induced decrease in the expression level of mRNA of the structural type-1 fimbrial components. Finally, we investigated the proteome of $E$. coli grown on both flat and nanorough substrates by 2-D differential in-gel electrophoresis (2D-DIGE). A significant number of proteins with differential expression were identified, involved in protein biosynthesis, protein transport, metabolic pathway, and DNA repair system, demonstrating that a pure topographical stimulus may directly and significantly affect the biological response/function of bacterial cells.

\section{RESULTS AND DISCUSSION}

In this work, we show how surface nanoroughness influences the biological response of bacteria in terms of cell morphology and variation of their gene expression and proteomic profile. To study the bacterial response to the surface topography of the substrates, we used highly controlled nanorough gold surfaces and classical glass slides as standard reference substrate for growth (control sample). Flat gold surfaces were used to evaluate possible contributions only due to the metal (internal control). The flat gold samples were fabricated by thermal evaporation onto premodified aminopropyltriethoxysilane (APTES) glass slides, whereas a precise and controlled level of gold nanoroughness was obtained by a wet chemistry approach (SGDR) (see Experimental Section). Figure 1 depicts the AFM analysis of glass, flat, and nanorough gold surfaces employed for the bacterial growth. The nanostructured substrate appeared uniformly rough with prominent high protrusions (Figure $1 \mathrm{C}$ ). The average surface roughness $\left(R_{\mathrm{a}}\right)$ was $\sim 100 \mathrm{~nm}$, while it was less than $1 \mathrm{~nm}$ for both the flat substrates (Figure 1A,B). AFM line profiles confirmed the precise control of the surface morphology, showing a homogeneous increase of nanoroughness in the sample $\mathrm{C}$. We also fabricated highly controlled substrates with intermediate levels of surface roughness, namely with $R_{\mathrm{a}}$ values of ca. 30,54,60, and $79 \mathrm{~nm}$ (Supporting Information, Figure S1, left column). The physical characteristics of glass, flat $\mathrm{Au}$, and all-rough $\mathrm{Au}$ substrates were further characterized by static water contact angle (WCA) measurements, both before and after the incubation with the bacteria culture medium (Figure 1D, and Supporting Information, Table S1). 

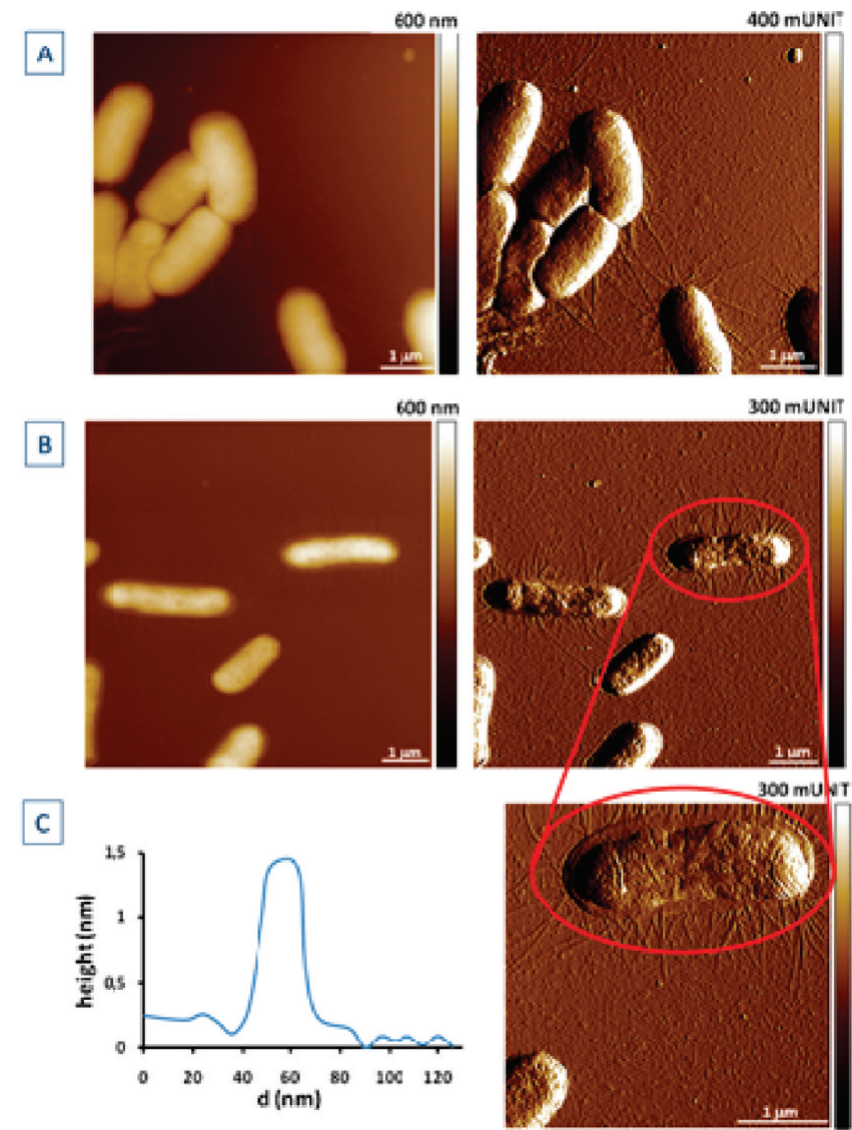

Figure 2. Representative AFM images of E. coli cells grown on glass (A) and flat gold (B) substrates, with topographical (left) and deflection (right) characterizations of bacteria; (C) zoom of the single E. coli cell shown in panel B which highlights fimbrial structures (right side) and typical line profile of a single fimbria (left side).

Experimental data revealed that, upon incubation with the medium, all the surfaces exhibited a similar hydrophilic character, likely due to adsorption of medium proteins on all the substrates. Furthermore, to exclude the presence of SGDR related $\mathrm{Ag}^{+}$residues onto the nanorough gold substrates, we carried out EDAX analyses, revealing that no contaminants were present (Supporting Information, Figure S2).

These substrates were used to study the behavior of E. coli upon adhesion. The morphology of the bacteria was examined by AFM, a powerful tool for bacterial imaging. ${ }^{38,39}$ We observed a clear change in the cell morphology of the bacteria grown on nanorough substrates, namely the absence of type- 1 fimbriae. Such structures are long and threadlike adhesive organelles (about 500 copies per cell) that enable bacteria to target and colonize specific host tissues. ${ }^{40,41}$ They increase the virulence of $E$. coli in the urinary tract by promoting bacterial persistence and enhancing the inflammatory response to infection. ${ }^{42}$ Also, their presence is crucial for starting the biofilm surface processes because they promote the bacterial adhesion and colonization on many surfaces. ${ }^{43-45}$ Figure 2 shows that bacteria attached on glass (Figure $2 \mathrm{~A}$ ) and flat gold surface (Figure $2 \mathrm{~B}, \mathrm{C}$ ) are $\sim 2$ $\mu \mathrm{m}$ long, $1 \mu \mathrm{m}$ wide, and $140 \mathrm{~nm}$ high; the typical type- 1 fimbriae filaments are clearly visible on these substrates with a width of $\sim 20 \mathrm{~nm}$ and average length of $1-3 \mu \mathrm{m}$, consistent with previous literature reports ${ }^{39}$ (the observed width of the fimbriae may be slightly affected by the lateral resolution limit of AFM). On the other hand, the bacteria adherent on the nanostructured surfaces (Figure 3) exhibited similar characteristics in terms of size and shape. However, the most intriguing morphological remark was that such bacteria did not phenotypically present fimbriae. We also incubated $E$. coli on gold substrates with different levels of surface nanoroughness, observing that also lower values of $R_{\mathrm{a}}$ (down to $20-30 \mathrm{~nm}$ ) are clearly sensed by the bacteria with a consequent loss of the fimbriae (Supporting Information, Figure S1). To further confirm such morphological evidence, we carried out SEM inspections of bacteria growing on flat and nanorough gold substrates (Supporting Information, Figure S3), demonstrating again the above-mentioned nanotopographyinduced biological response. To the best of our knowledge, this is the first time that the fimbrial structures are not expressed by bacteria as a consequence of a pure nanotopographic cue. From our data, assuming that nanoroughness consists of arrays of nanostructures with hemispherical shape, we infer that a surface topographical perturbation of the order of $0.01 \%$ in terms of the 

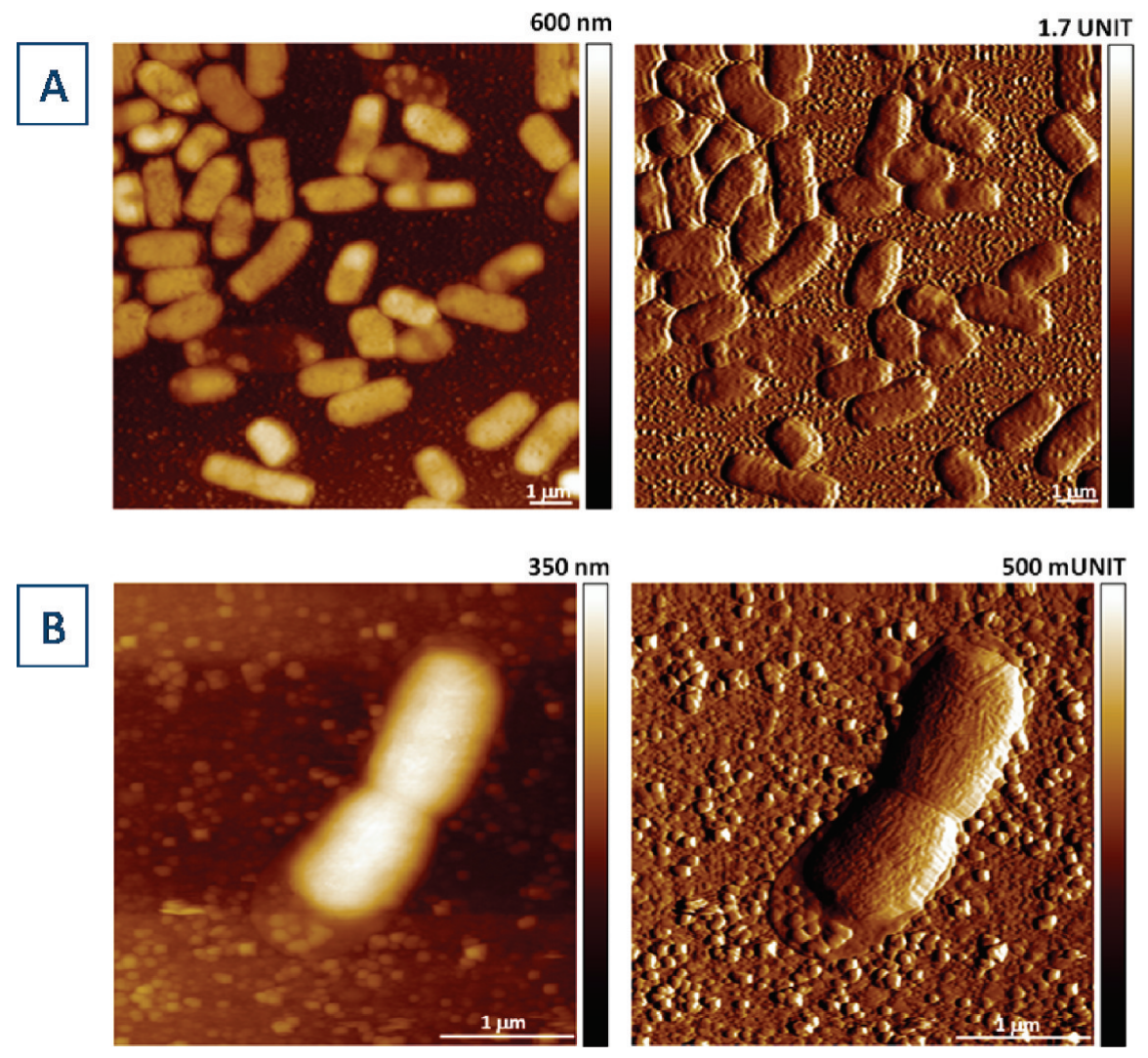

Figure 3. Typical AFM images of E. coli cells grown on nanorough substrates. (A) Scan area $10 \times 10 \mu \mathrm{m}^{2}$, (B) scan area $4 \times 4$ $\mu \mathrm{m}^{2}$ (left, topographical pictures; right, deflection characterizations). No fimbriae are manifested by the bacteria in this case.

nanostructure/bacterium volume ratio is sufficient to elicit a strong response in bacterial cells. On the other hand, we did not observe any significant difference in the number of adherent E. coli among the different substrates (Supporting Information, Figure S4).

To better understand the biological mechanism responsible for such a striking morphological change, we quantified the expression of genes used in production of fimbriae by RT-qPCR assays, upon interaction and adhesion on such nanotopographies. The differential expression of type-1 fimbriae, known as "phase variation", is associated with the inversion of a short element of DNA that is situated in the fim gene cluster. ${ }^{46}$ This cluster contains a promoter which directs the transcription of all the fimbrial structural genes (i.e., fimA, fiml, fimH) in one but not in the other orientation (fim operon in "ON" or "OFF" orientation, respectively) ${ }^{46,47}$ resulting in "all-ornothing" expression level (Figure 4A). The inversion reaction can be catalyzed by LrhA transcriptional regulator (whose direct or indirect activity has not been yet fully clarified), ${ }^{48}$ or can be governed by other factors. ${ }^{47}$ In our experiments, a significant difference of mRNA expression level was found in the regulation of the fim operon in the bacteria grown on the nanorough surfaces as compared to the control glass surfaces (no significant differences were detected between glass and flat gold surface, see Supporting Information, Figures S6-8). In particular, the expression level of fimA, which encodes the major subunit of type-1 fimbriae, and fiml, that is a structural component under the control of the same promoter, were approximately $57 \pm 3 \%$ and $75 \pm 5 \%$ for bacteria grown on the nanorough substrates with respect to the bacteria grown on glass substrates (Figure $4 B$ ). In addition, we found that the expression level of $\operatorname{Irh} A$, which encodes the repressor of the fim operon, is $127 \pm 6 \%$ for bacteria grown over rough substrates (Figure 4B) (realtime curves, quantifications of the three genes, and related melting curves are reported in Figures S9-S12). These data confirm the previous experimental evidence that LrhA acts as a repressor of the fimbrial genes expression ${ }^{48}$ (Figure 4C). These first genetic results revealed that nanorough Au surfaces lead to a loss of expression of such bacteria virulence factors. It is noteworthy that slight modifications of the surface morphology of the substrates are sensed by bacteria, which actively respond at genetic level (however, an important role in the fimbrial secretion is also due to post-transcriptional mechanisms). ${ }^{49}$

To further understand if the loss of fimbriae was a transient or a permanent phenomenon, we grew E. coli on the nanorough gold substrates followed by a replica painting of such bacteria adherent on the substrates, that is, we placed their surface over an agar-solidified culture medium. We then picked up some bacteria colonies, incubating them on normal glass slides. As revealed by AFM inspections (Figure 5), bacteria recovered again the expression of fimbriae. This indicates that slight changes 


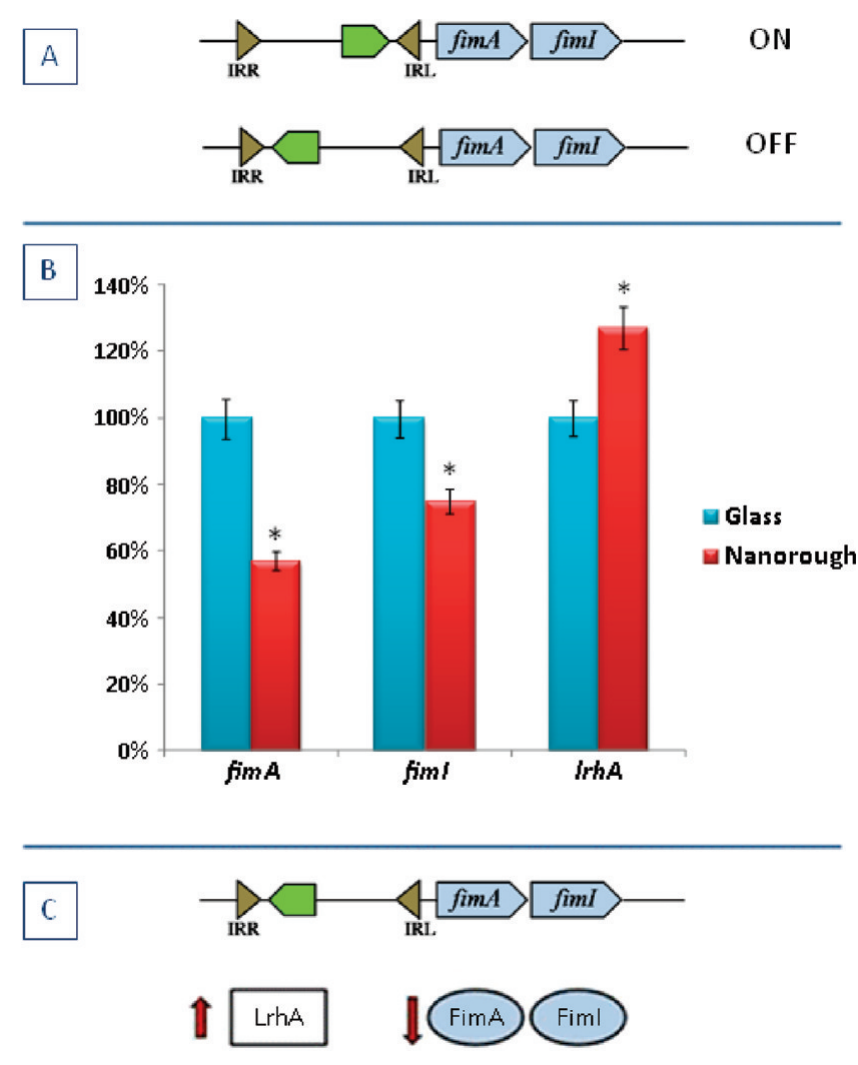

Figure 4. Expression analysis of fim and IrhA genes in bacteria grown on nanorough surfaces as compared with bacteria grown on glass surface (control). (A) General mechanism of fimbrial operon. LrhA promotes the inversion of the DNA segment containing the promoter for the fimbrial structural genes. (B) Expression levels of fimA, fiml, and IrhA in the treated bacteria compared to control bacteria (set at $100 \%$ ). Data are shown as means \pm standard deviations from three independent experiments $(*=p<0.001)$. (C) Proposed mechanism of regulation of type-1 fimbriae synthesis on nanorough surfaces: the increased level of LrhA results in the down-expression of FimA and Fiml.

in surface topography led to a transient phase variation of fimbrial expression. Hence, the interaction between bacteria and surfaces is a critical step for the modulation of bacteria properties.

These remarkable observations led us to investigate the entire proteomic profile of $E$. coli, upon interaction with nanorough substrates, by the 2D-DIGE proteomic technique. 2D-DIGE is a well established and powerful method that allows one to understand and clarify specific metabolic pathways of cells by highlighting up- or downexpression of proteins. ${ }^{50-52}$ Figure 6A shows a representative $2 \mathrm{D}$ gel in which $\sim 1500$ protein spots of $E$. coli grown on both glass and nanorough gold substrates were identified. We used strips with a 4-7 $\mathrm{pH}$ gradient for the first dimension to better resolve the bacterial proteomic profile (Figure 6A). The quality of our 2D-DIGE experiments was demonstrated by a variance below $15 \%$ for 1500 spots within the biological replicates; ${ }^{53}$ at the same time, also the principal component analysis (PCA) (Figure 6B) clearly displayed two well-resolved populations. Yellow spots (which represent the population of control proteins pool) are in fact grouped together in the left side of the spot maps and are well separated from the red spots (representing the treated population) ${ }^{54}$ (Figure $6 \mathrm{~B}$ ). Among the $\sim 1500$ protein spots in the $2 \mathrm{D}$ gel, we identified 15 of them which were differentially expressed (up- or down-regulated) with significant statistical validity $[t$ test $<0.01$ between glass (control) and nanorough (treated)] (no significant differences were detected between glass and flat gold surface, see Supporting Information, Figure S13). These 15 significant spots, representative of 15 proteins, showed up and down trends of regulation, as shown by the extended data analysis (EDA) displayed in Figure 6C. The expression levels are visualized as different chromatic scales; in particular, as elucidated by the legend on the bottom-left side of Figure $6 \mathrm{C}$, the shift from bright green (down-expression) to bright red (overexpression) colors illustrates the trend of proteins expression. ${ }^{55}$

Protein identification was performed by picking up the 15 significant spots, from the corresponding preparative gel, and carrying out LC-MS/MS mass spectrometry analyses (Supporting Information, Table S14). We observed that the presence of nanotopography alone, without chemical or biological external stimuli/ surface modifications, induces a different expression of proteins involved in transcription regulation, transport of oligopeptides and aminoacids, energy metabolism, stress response, and synthesis and modification of macromolecules (Table 1). 

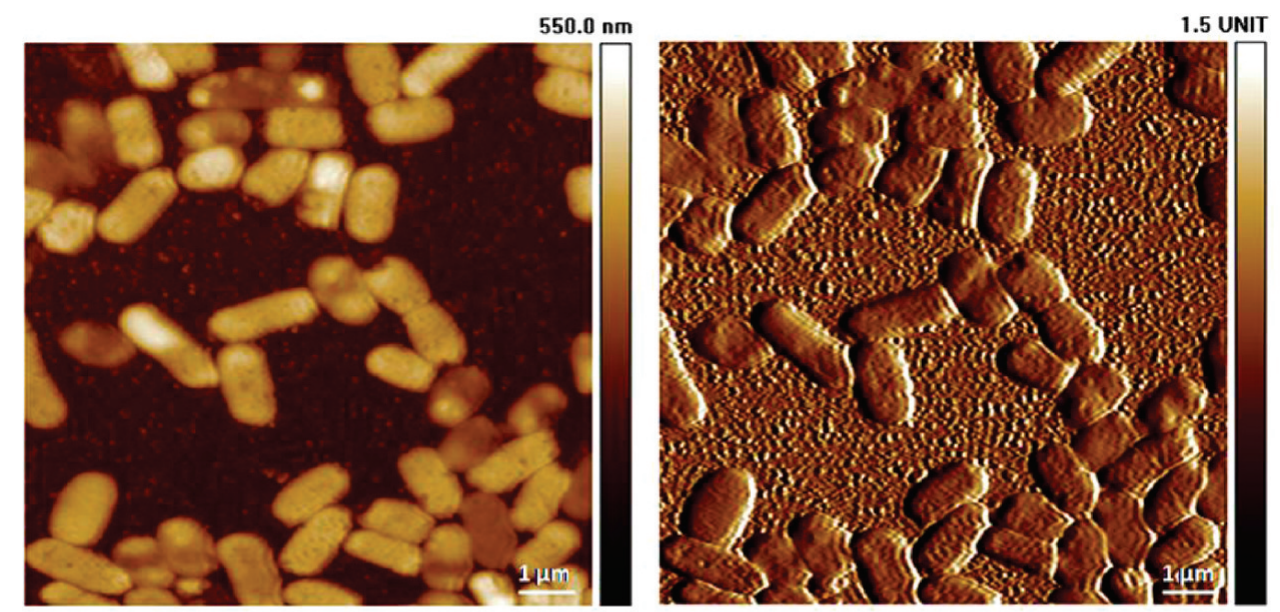

.5 UNIT
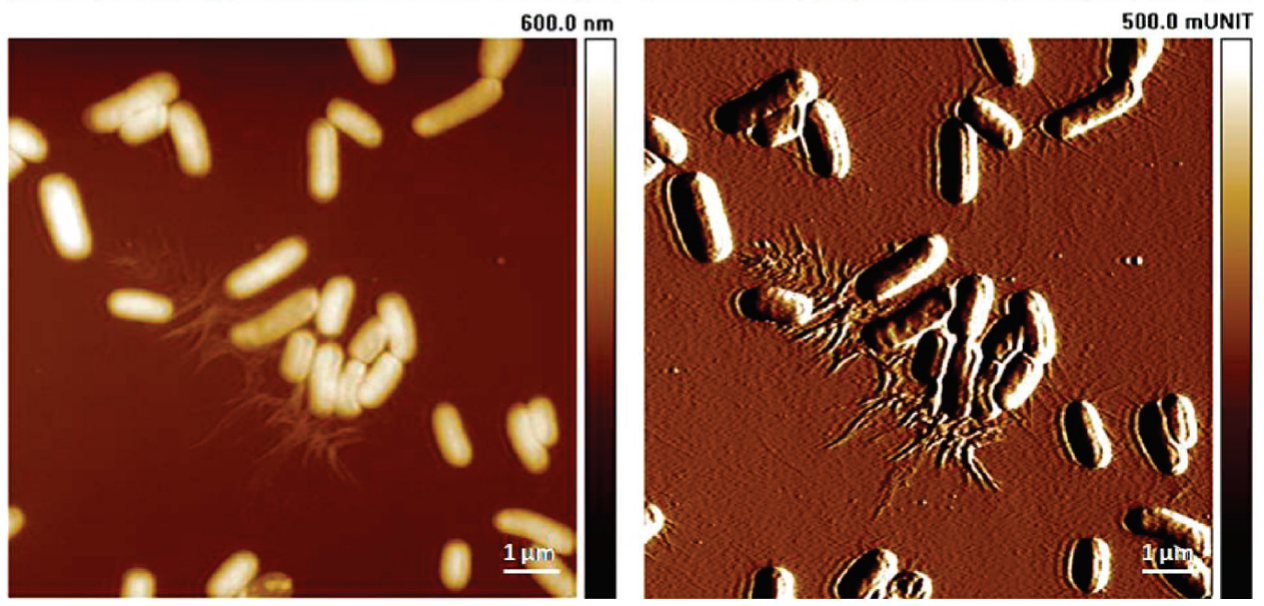

Figure 5. AFM investigations of replica painting experiments. E. coli was first grown on nanostructures gold substrates (top row), confirming the loss of fimbriae. Such substrates, with adherent bacteria, were deposited on an agar-solidified culture medium, and some bacterial colonies were picked up and grown on normal glass slides (bottom row). AFM revealed that E. coli was able to recover the fimbrial structures (left, topography; right, deflection).

In particular, we found that some proteins involved in the general stress response were regulated in the nanorough samples. For instance, the DNA protection during starvation protein (Dps), that represents one example of defense against oxidative DNA damage in actively growing cells, ${ }^{56}$ was up-regulated. At the same time, also the OsmC stress-inducible membrane protein (whose transcription is typically induced at elevated osmotic pressure) codified by the osm C gene ${ }^{57}$ was up-regulated. Such latter finding is also confirmed by the down-regulation of the $\mathrm{H}-\mathrm{NS}$ transcriptional regulator, which is a histone-like protein able to repress the expression of numerous genes, including osmC. ${ }^{58}$ We also found that several proteins involved in general cell processes were regulated; in this frame, the overexpression of the YaeT complex is of particular interest, as it is required for the outer membrane $\beta$-barrel proteins (OMPs) assembly that is important for a proper maintenance of the outer membrane, required for cell viability. ${ }^{59}$ In addition, the NusA protein, involved in transcription termination in the tryptophan operon of E. coli $^{60}$ and the periplasmatic histidine binding protein (HBP), that is an initial receptor in the process of active transport across cell membranes and/or chemotaxis, ${ }^{59}$ are both up-regulated in the bacteria interacting with the nanorough surfaces. On the other side, the oligopeptide transport OppA, ${ }^{61}$ the outer membrane protein A (OMPA), that plays a structural role in the integrity of the bacterial cell surface, ${ }^{62}$ and protein YgiW are down-expressed. These observations indicate that nanostructured surfaces strongly affect $E$. coli cells, leading to general stress processes in bacteria, which activate defense mechanisms against DNA or membrane damage. Moreover, we detected proteins important for the synthesis and modification of macromolecules. The $\beta$-subunit of the glycyl-tRNA synthetase, an important enzyme in protein synthesis, ${ }^{63}$ and the dihydrodipicolinate synthase, a crucial target enzyme of many antibiotics, ${ }^{64}$ resulted overexpressed. On the other hand, the uracil phosphoribosyltransferase, which is the precursor for all pyrimidine nucleotides (pyrimidine salvage enzyme), ${ }^{65}$ is down-regulated. Finally, we found that the energy metabolism proteins transketolase $2^{66}$ and pyruvate kinase ${ }^{67}$ were both up-regulated in treated samples. Overall, such protein pattern suggests that $E$. coli undergoes important changes in the metabolic pathways upon interaction with nanostructured surfaces, confirming that nanoroughness alone causes a general 

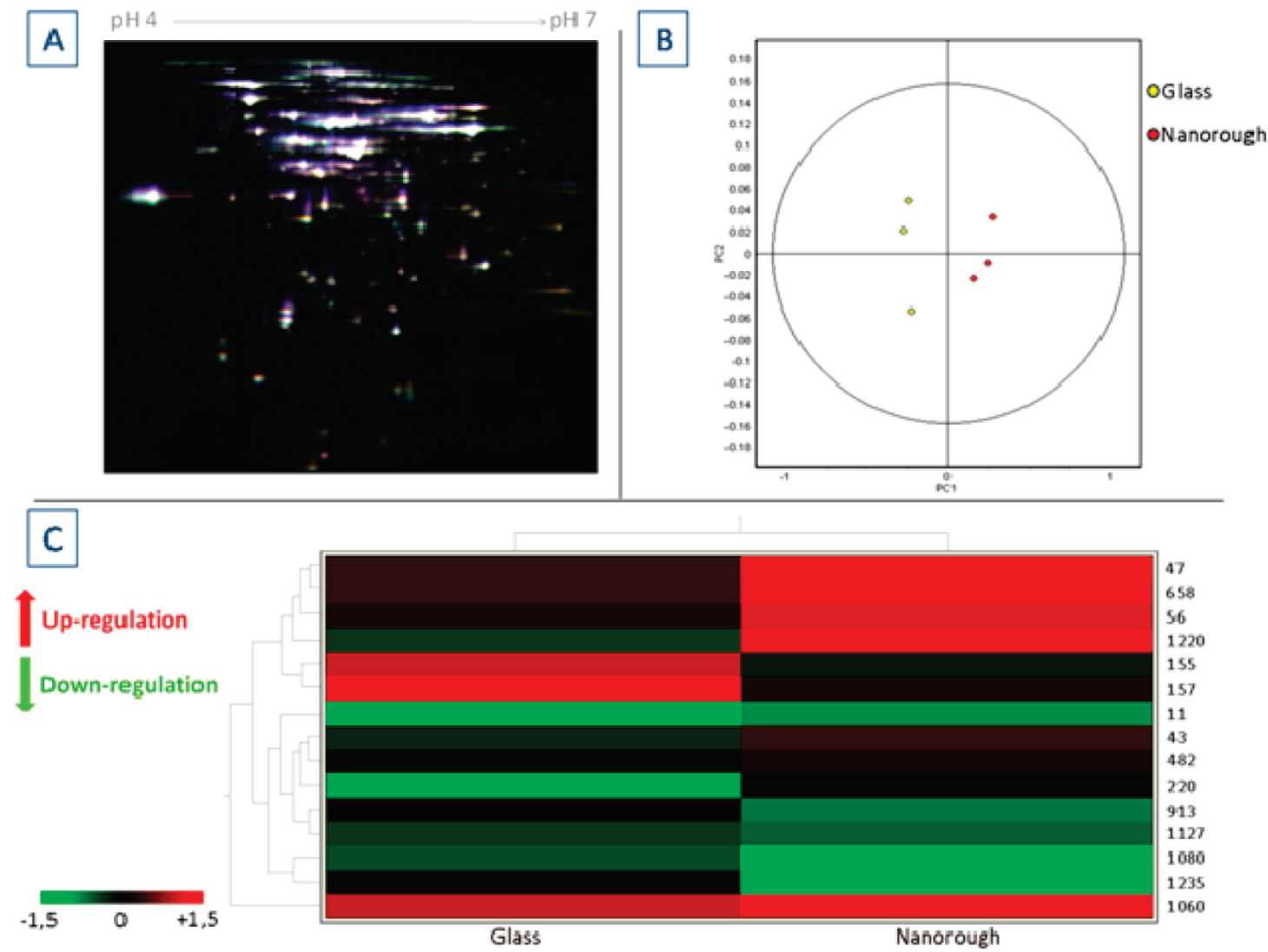

Figure 6. DIGE analysis of bacteria grown on rough substrates (treated) vs bacteria grown on glass substrates (control). (A) A representative DIGE gel. The proteins pool from control bacteria (grown on glass) was conjugated with Cy3, the proteins pool derived from treated bacteria (grown on nanorough gold surfaces) was labeled with $\mathrm{Cy} 5$, while the pooled internal standard (mix of control and treated proteins) was labeled with Cy2. (B) PCA hierarchical clustering analysis: the glass and nanorough groups are well separated indicating good statistical populations of up- and down-expressed proteins (analyses from three biological replicates). (C) The DeCyder 2D EDA of differentially expressed proteins shows a trend for down-regulation (green) and up-regulation (red) of proteins for glass and nanorough samples.

stress condition in the bacteria. A possible explanation is that the nanotopography causes a significantly reduced contact area of the bacteria with the underlying substrate, likely perturbing their anchoring mechanisms. This might also lead to damages of the outer membrane of adherent $E$. coli, which consequently rearranges its protein expression profile up-regulating enzymes involved in the protection of DNA, aminoacid synthesis, energy production, regulation, and rearrangement of the external membrane; at the same time, E. coli down-regulates some transport proteins and enzymes related to DNA synthesis, possibly trying to avoid mistakes and/or damages during base synthesis.

\section{CONCLUSIONS}

In this work we have demonstrated that nanostructured substrates induce important variations in the morphological, genetic, and proteomic response of adherent $E$. coli. AFM and SEM investigations revealed a significant alteration of bacterial morphological characteristics, with a specific effect concerning the loss of type- 1 fimbriae. Since fimbriae are adhesive organelle involved in adhesion of bacteria to specific cells of host tissues, this finding is quite intriguing. The $\mathrm{QPCR}$ results also confirmed a genetic phase variation phenomenon, regarding the "OFF" operon fimbrial switching for bacteria grown on nanorough substrates. Finally, the 2D-DIGE analysis revealed a different expression pattern of $E$. coli adherent on nanostructured surfaces (as compared to reference flat substrates) of proteins involved in biosynthesis, peptide transport, metabolic pathway, and DNA repair system. These data highlighted two important issues: First, even an apparently weak physical stimulus, that is, a nanoscale variation in surface topography, may cause important responses in E. coli, such as loss of fimbriae and modulation of its protein expression pattern. Second, in addition to the physicochemical investigations, deep biochemical and molecular biology approaches are very important to study the interaction processes of bacteria with inorganic surfaces. We believe that the understanding of the bacterial responses and adaptations to nanostructured surfaces will open interesting perspectives for the design of novel and more efficient implant devices with unanimously certified antibacterial characteristics.

\section{EXPERIMENTAL SECTION}

Substrates Fabrication and Characterization. For substrates preparation, $1.5 \mathrm{~cm} \times 1.5 \mathrm{~cm}$ glass slides were first 
TABLE 1. E. coli Genes Affected by Interaction with Nanorough Substrates ${ }^{a}$

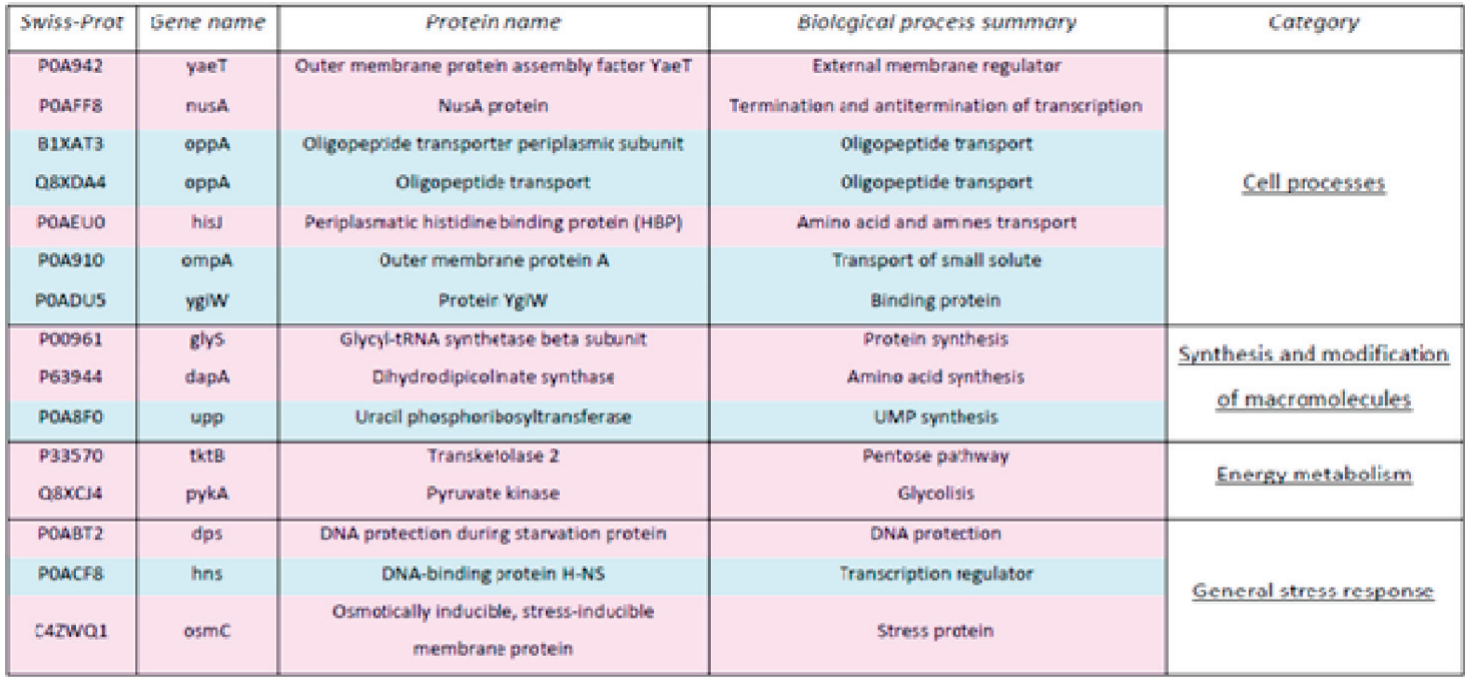

Legend:

Down regulation

Up regulation

${ }^{\text {a }}$ The molecular functional compositions of the proteins were based on Gene Ontology annotation. A total of four functional categories were obtained by inspecting Swiss - Prot queries.

sonicated with ultrapure water (resistivity $18.2 \mathrm{M} \Omega \mathrm{cm}$; ELGA) for $15 \mathrm{~min}$ and then treated with a 1:1:5 solution of $30 \% \mathrm{NH}_{3} \mathrm{OH}$ (J. T. Baker), $30 \% \mathrm{H}_{2} \mathrm{O}_{2}$ (J. T. Baker), and water at $75{ }^{\circ} \mathrm{C}$ for $10 \mathrm{~min}$, followed by treatment with a 1:1:5 solution of $30 \% \mathrm{HCl}$ (J. T. Baker), $30 \% \mathrm{H}_{2} \mathrm{O}_{2}$, and water at $75{ }^{\circ} \mathrm{C}$ for $10 \mathrm{~min}$, with intermediate washing steps with deionized water after each treatment. Subsequently, the cleaned surfaces were exposed to $300 \mu \mathrm{L}$ of $1 \%$ aminopropyltriethoxysilane (APTES, Sigma-Aldrich) aqueous solution for $5 \mathrm{~min}$, washed with deionized water, and kept in vacuum overnight to remove the unbound APTES molecules. These $\mathrm{NH}_{2}$-modified glass substrates were coated with $50 \mathrm{~nm}$ Au film by thermal evaporation ( $1 \AA /$ s of evaporation rate), to obtain a very flat and uniform gold film. For the preparation of gold substrates with different levels of surface roughness, the amino-modified glass slides were first coated with $50 \mathrm{~nm}$ of Au film and then with increasing values of Ag film ( $1.5 \AA / s$ of evaporation rate), namely $10,20,30,40$, and $50 \mathrm{~nm}$. After the silver coating they were exposed to $10^{-3} \mathrm{M} \mathrm{HAuCl}_{4}$ (SigmaAldrich) aqueous solution for $15 \mathrm{~min}$ for the SGDR reaction. ${ }^{37}$ All the substrates were washed two times with $1 / 20$ of $30 \%$ ammonia (J. T. Baker) for 20 min to dissolve the $\mathrm{AgCl}$ residues of the SGDR, rinsed three times with ultrapure water, dried under nitrogen flow, and stored overnight in a drier. All the substrates were characterized by AFM. The wettability properties of the various glass/flat/ nanorough substrates were assessed by measuring the static water contact angle (WCA) of double distilled water drops dispensed with a microsyringe onto the surfaces, with the sessile drop method. We used a CAM200-KSV instrument equipped with a digital camera to take magnified images of the microdroplets. The static WCA analyses of the substrates before and after incubation with the bacterial culture medium were performed on overnight dried samples.

Bacterial Strain and Growth Conditions. A loop of glycerol stock of $E$. coli strain $\mathrm{TG} 1^{68}[\mathrm{~K} 12$, lac-pro supE thi hsdD5 $\left(\mathrm{F}^{\prime}\right.$ traD36 proA $^{+} B^{+}$lacl $^{q}$ lacZ M15)] was streaked onto a Luria-Bertani medium agar plate and incubated overnight at $37{ }^{\circ} \mathrm{C}$. Then a single colony was picked and grown in LB liquid medium overnight at $37^{\circ} \mathrm{C}$ up to an optical density at $600 \mathrm{~nm}\left(\mathrm{OD}_{600}\right)$ of $1.00 \pm 0.05$ (corresponding to $\sim 8 \times 10^{8}$ cells $/ \mathrm{mL}$ ) in a shaking incubator (240 rpm). The overnight culture was diluted in $\mathrm{LB}$ medium to an $\mathrm{OD}_{600}$ of 0.1 and transferred into a six-well plate containing the substrates. The plates were incubated at $37{ }^{\circ} \mathrm{C}$ for $24 \mathrm{~h}$ with shaking (240 rpm). After the incubation, the surfaces were gently rinsed four times with $0.2 \mathrm{M}$ Tris, $\mathrm{pH} 7.5$ to analyze only surface-associated bacteria.

Samples Preparation for AFM and SEM Analyses. Before performing AFM and SEM investigations, bacteria cells growing on glass slides and flat and nanorough gold surfaces were fixed and dried following different steps. The substrates with adherent bacteria were first transferred in a solution containing $4 \%$ formaldehyde (Aldrich) in PBS buffer (Aldrich), then samples were allowed to fix for $5 \mathrm{~min}$ and washed in deionized water for $10 \mathrm{~min}$. After this, the samples were dehydrated using a series of ethanol washing: (1) 30\% ethanol for $10 \mathrm{~min}$, (2) $50 \%$ ethanol for $10 \mathrm{~min}$, (3) 70\% ethanol for $10 \mathrm{~min}$, (4) $90 \%$ 
ethanol for $10 \mathrm{~min}$, (5) 100\% ethanol for $10 \mathrm{~min}$ (repeated two times). Samples were then immersed in hexamethyldisilazane (HMDS, Aldrich) for $15 \mathrm{~min}$, dried at room temperature, and immediately analyzed. ${ }^{68}$

Atomic Force Microscopy, Scanning Electron Microscopy, and EDAX Measurements. The topography of the Au surfaces and bacteria grown on the surfaces was characterized by atomic force microscopy. All the experiments were performed in contact mode in air, using the commercial Nanoscope IV MultiMode SPM (Veeco Instruments, Santa Barbara, CA) under ambient conditions $\left(20-25^{\circ} \mathrm{C}\right.$, atmospheric pressure, $\sim 50 \%$ humidity). Ultrasharp silicon nitride cantilevers (triangular, DNP, Veeco Instruments, Santa Barbara, CA) were used with a spring constant of $0.58 \mathrm{~N} \mathrm{~m}^{-1}$ and a normal tip radius of $10 \mathrm{~nm}$. Several images were obtained from separate locations of the surfaces to ensure reproducibility (for each replicate, five scan fields of $10 \times 10 \mu \mathrm{m}^{2}$ were analyzed, finding a mean number of bacteria of $41 \pm 8$ for each field). All the images were analyzed using the NanoScope software (Digital Instruments), version 6.0.

For morphological investigations by SEM, samples were treated as previously discussed, and analyses were carried out with a Nova NanoSEM200 (FEI). Samples were positioned at a working distance of $5 \mathrm{~mm}$, and scanned with a $18 \mathrm{KeV}$ e-beam. The SEM is also equipped with a UVW Shappire EDAX Microanalysis detector, thus allowing energy dispersive $\mathrm{X}$-ray mapping with spatial resolution better than $1 \mu \mathrm{m}$ (11 keV of acquisition).

Confocal Microscopy. To count the number of adherent bacteria, substrates were immersed in $4 \%$ formaldehyde (to fix cells) and then stained with Hoechst 33258 ( $1 \mu \mathrm{g} / \mathrm{mL}$ final concentration); imaging was performed by a confocal microscopy (Leica TCS-SP5 AOBS), and direct counting was carried out onto glass, flat, and all the nanorough samples. For each replicate (3 independent replicates were used), 10 scan fields of $400 \times 400 \mu \mathrm{m}^{2}$ were analyzed.

Determination of fim and IrhA Transcript Levels by Quantitative, One-Step Real-Time PCR. The expression of three different genes (fimA, fiml, and IrhA) was investigated for bacteria grown on glass and flat and rough gold substrates by real-time qPCR. The gapA gene, encoding $D$-glyceraldehyde-3-phosphate dehydrogenase $A$, was used as an independent internal control. The bacteria growth conditions were as described earlier (section "Bacterial Strain and Growth Conditions"). After the incubation with substrates (three independent biological replicates), the surfaces were gently rinsed four times with $0.2 \mathrm{M}$ Tris, $\mathrm{pH} 7.5$ to analyze only surface-associated bacteria. The total RNA was extracted from bacterial cells of each sample (glass, flat, and nanorough gold substrates) using TRI Reagent (Sigma-Aldrich), as described in the manufacturer's instructions, giving special attention to detach only adherent bacteria. The amount of mRNA of each sample (glass, flat gold, and rough gold) was determined by taking the optical density (OD) 260/280 ratio using a UV-vis

\section{TABLE 2}

\begin{tabular}{lll}
\multicolumn{1}{c}{ primer } & \multicolumn{1}{c}{ sequence $\left(\mathbf{5}^{\prime} \rightarrow \mathbf{3}^{\prime}\right)$} & ref \\
\hline FimA forward & GGA CAG GTT CGT ACC GCA TC & 48 \\
FimA reverse & ACG TTG GTA TGA CCC GCA TC & 48 \\
Fiml forward & GAC GGT CAA TAT GGG GCA AA & 48 \\
Fiml reverse & TTT TTA CCA TCC GCG ACA CC & 48 \\
LrhA forward & CGC GTG AGT TCG GTT TAT CC & 68 \\
Lrha reverse & CTG CGC AGT ACC AGT GTG TTG & 68 \\
GapA forward & GTT GTC GCT GAA GCA ACT GG & 48 \\
GapA reverse & AGC GTT GGA AAC GAT GTC CT & 48 \\
\hline
\end{tabular}

spectrophotometer, and RNA quality was analyzed using agarose gel electrophoresis (1.2\%, $70 \mathrm{~V}$ for $30 \mathrm{~min}$ ) (see Supporting Information, Figure S5). The PCR was carried out using the primers sequence reported in Table $2 .{ }^{48} \mathrm{PCR}$ was performed using direct total RNAs in one-step reaction in a ABI 7500 thermal cycler (Applied Biosystems). For each gene, we prepared five PCR mixtures with a final volume of $20 \mu \mathrm{L}$ each. Each PCR mixture contained $5 \mu \mathrm{L}$ of $0.2 \mu \mathrm{g} / \mu \mathrm{L}$ of RNA solution mixed with $10 \mu \mathrm{L}$ of $10 X$ Express Syber Green qPCR SuperMix premixed with ROX (Invitrogen), $0.4 \mu \mathrm{L}$ of $10 \mu \mathrm{M}$ of each gene specific primers (forward and reverse), $0.5 \mu \mathrm{L}$ of Express SuperScript Mix for one-Step Syber GreenER (Invitrogen), and $6.5 \mu \mathrm{L}$ of DEPCtreated water. Reaction conditions for all genes were $50^{\circ} \mathrm{C}$ for $5 \mathrm{~min}$ and $95^{\circ} \mathrm{C}$ for 2 min to perform cDNA synthesis, immediately followed by PCR quantification program, repeated 40 times $\left(15 \mathrm{~s}\right.$ at $95{ }^{\circ} \mathrm{C}, 1 \mathrm{~min}$ at $60^{\circ} \mathrm{C}$ ). This program was followed by a melting curve program (60-95 ${ }^{\circ} \mathrm{C}$ with a heating rate of $0.1{ }^{\circ} \mathrm{C} / \mathrm{s}$ and continuous fluorescence measurements). Specificity for all amplicons was confirmed via melting curves and gel analysis. The threshold cycle for each real-time PCR was determined by using the software package supplied with the $A B I 7500$ thermal cycler, and gene expression was calculated by the Delta-Delta CT method.

Preparation of Protein Samples for Proteomic Analyses. The substrates used for cultures (three independent biological replicates) were washed four times with sterile PBS and resuspended with $0.1 \mathrm{M}$ Triton X-100 solution and $1 \mathrm{X}$ protease inhibitor (Protease Inhibitor Cocktail Set III, Novagene). The cell suspension was incubated on a shaking platform for $20 \mathrm{~min}$ at room temperature followed by four cycles of sonication (each for $10 \mathrm{~s}$ at $10 \%$ of maximum output; high-intensity ultrasonic liquid processor; Sonics, Newtown, USA). Soluble proteins were obtained by centrifugation of the cell extract at $16000 \mathrm{~g}$ for $2 \mathrm{~min}$ at $4{ }^{\circ} \mathrm{C}$. The supernatant was collected and the protein concentration was determined by the Bradford assay using bovine serum albumin as a standard. Following extraction, the protein samples were prepared for 2D-DIGE using 2D Clean-Up Kit (GE Healthcare); in this way, any other interfering components were removed. The samples were resuspended in DIGE labeling buffer with $7 \mathrm{M}$ urea, $2 \mathrm{M}$ thiourea and 4\% CHAPS, $30 \mathrm{mM}$ Tris $\mathrm{pH} 8.5$. The protein solutions were then centrifuged at $12000 \mathrm{~g}$ 
for $10 \mathrm{~min}$ to remove any insoluble material and to reduce any foam. The $\mathrm{pH}$ of the protein extract was adjusted to 8.5 by adding $50 \mathrm{mM} \mathrm{NaOH}$, and protein concentration was determinated by the Bradford assay (Biorad). The samples were stored at $-80{ }^{\circ} \mathrm{C}$ until use.

2D-DIGE Experiments. Protein extracts obtained from E. coli cultured on different substrates were labeled with cyanine dyes according to the manufacturer's instructions (Amersham Biosciences, Piscataway, NJ). Briefly, $50 \mu \mathrm{g}$ of proteins from $E$. coli were labeled with $400 \mathrm{pmol}$ of amine reactive cyanine dyes, $\mathrm{Cy} 3$ or $\mathrm{Cy} 5 \mathrm{~N}$-hydroxysuccinamide (NHS) ester DIGE dyes (Amersham Bioscences), freshly dissolved in anhydrous dimethyl formamide. Then, the samples were mixed with a Cy2-labeled internal pooled standard. The internal pooled standard sample was prepared by pooling $50 \mu \mathrm{g}$ of proteins from each sample. No primary amines, DTT, or carrier ampholytes were included in the buffer as such components could potentially react with the NHS esters of the cyanine dyes. The labeling mixture was incubated in ice in the dark for $30 \mathrm{~min}$, and the reaction was terminated by addition of $10 \mathrm{mM}$ lysine followed by incubation in ice for additional $10 \mathrm{~min}$. The quenched Cy3- and Cy5-labeled samples were then combined with the quenched Cy2-labeled pool internal standard. The total proteins $(150 \mu \mathrm{g})$ were mixed and denatured in 2-D sample buffer (7 M urea, $2 \mathrm{M}$ thiourea, 4\% CHAPS, 2\% DTT, 2\% IPG 4-7 NL buffer, 0.04\% bromophenol blue), and the final loading volume was $450 \mu \mathrm{L}$.

2D Separation and Image Analyses. All 2-D separations were performed using the Amersham Biosciences DIGE apparatus (Amersham Biosciences). In brief, Immobiline DryStrips pH 4-7 NL $\times 24 \mathrm{~cm}$ (Amersham Biosciences) were used for the first dimension separation with the cup-loading technique. IEF was carried out on a MultiPhor electrophoresis system (Amersham Biosciences). The electrophoresis conditions were set at $20^{\circ} \mathrm{C}$. The following protocol was used: step 1, $150 \mathrm{~V}$ for $3 \mathrm{~h}$; step 2, $300 \mathrm{~V}$ for $3 \mathrm{~h}$; step 3, $1000 \mathrm{~V}$ for $6 \mathrm{~h}$; step 4, voltage gradient from 1000 to $10000 \mathrm{~V}$ for $1 \mathrm{~h}$; step 5, $10000 \mathrm{~V}$ for $3 \mathrm{~h}$. After IEF, the strips were equilibrated in buffer containing $6 \mathrm{M}$ urea, $2 \%$ SDS, 30\% glycerol, $50 \mathrm{mM}$ tris $\mathrm{pH} 8.8,0.02 \%$ bromophenol blue, $30 \mathrm{mM} \mathrm{DTT}$, and subsequently with $240 \mathrm{mM}$ iodoacetamide to allow the cysteine residues to be reduced and then carbamidomethylated. The strips were immediately subjected to the second dimensional separation in an ETTAN Dalt Six electrophoresis system (Amersham Biosystem) using a $12.5 \%$ SDS-polyacrylamide gel. Initially, gels were run at $25 \mathrm{~mA} / \mathrm{gel}$ for $10 \mathrm{~min}$ and then were increased to $50 \mathrm{~mA} / \mathrm{gel}$ after the proteins migrated into the resolving gel. The CyDye-labeled gels were visualized using a Typhoon 9400 imager (Amersham Biosciences). Excitation and emission wavelengths were chosen specifically for each dye, according to the manufacturer's recommendations for each DIGE fluorophore: Cy2 (488/520 nm), Сy3 (532/580 nm), and Cy5 (633/670 nm). Images were preprocessed to remove areas extraneous to those of interest using ImageQuant V2005 (Amersham Biosciences). The gel analysis was performed using the DeCyder Difference In-gel Analysis (DIA) version 6.5.11 (Amersham Biosciences). Intergel matching was performed using Decyder Biological Variance Analysis (BVA) version 6.5.11 (Amersham Biosciences), and statistical analyses were carried out for each sample. The estimated number of spots for each codetection procedure was set to 2500 . Each gel was first grouped into "glass" and "nanorough" to allow for comparison between the control and the treated groups. The spots on each standard gel were then screened carefully to ensure that they were matched correctly across all gels. Student's $t$ test analysis was performed for each matched spot set, comparing the average and standard deviation of protein abundance for a given spot between the control and treated groups to find significant differences above the experimental variation.

Protein Identification by LC-MS/MS and Database Search. To allow MS analysis for protein identification, $500 \mu \mathrm{g}$ of E. coli proteins pool were used to produce a preparative gel. After performing 2-D PAGE as described above, the gels were washed three times in deionized (DI) water, stained in GelCode Blue Stain Reagent (Pierce) overnight, and washed three times in DI water for more than $4 \mathrm{~h}$ before being scanned, wrapped in plastic, and stored at $4{ }^{\circ} \mathrm{C}$. After confirming that all 2-D DIGE marker spots were matched correctly to the corresponding 2-D PAGE gel spots, the preparative gel spots were excised from the gel and washed in $50 \mathrm{mM}$ ammonium bicarbonate $\mathrm{pH} 8.0$ in $50 \%$ acetonitrile to a complete destaining. The gel pieces were resuspended in $50 \mathrm{mM}$ ammonium bicarbonate $\mathrm{pH}$ 8.0 containing $100 \mathrm{ng}$ of trypsin and incubated for $2 \mathrm{~h}$ at $4{ }^{\circ} \mathrm{C}$ and overnight at $37^{\circ} \mathrm{C}$. The supernatant containing the resulting peptide mixtures was removed, and the gel pieces were re-extracted with acetonitrile. The two fractions were then collected and freeze-dried. The peptide mixtures were analyzed by LC-MS/MS using the LC/MSD Trap XCT Ultra (Agilent Technologies, Palo Alto, CA) equipped with a 1100 HPLC system and a chip cube (Agilent Technologies). After loading, the peptide mixture (7 $\mu \mathrm{L}$ in $0.5 \%$ TFA) was first concentrated at $4 \mu \mathrm{L} / \mathrm{min}$ in a $40 \mathrm{~nL}$ enrichment column (Agilent Technologies chip), with $0.1 \%$ formic acid as the eluent. The sample was then fractionated on a C18 reverse-phase capillary column (75 mm $\times 43 \mathrm{~mm}$ in the Agilent Technologies chip) at a flow rate of $300 \mathrm{~nL} / \mathrm{min}$, with a linear gradient of eluent $B$ ( $0.1 \%$ formic acid in acetonitrile) in A ( $0.1 \%$ formic acid) from 7 to $50 \%$ in $35 \mathrm{~min}$. Elution was monitored on the mass spectrometers without any splitting device. Peptide analysis was performed using data-dependent acquisition of one MS scan ( $\mathrm{m} / \mathrm{z}$ range from 400 to $2000 \mathrm{Da} / \mathrm{e}$ ) followed by MS/MS scans of the three most abundant ions in each MS scan. Dynamic exclusion was used to acquire a more complete survey of the peptides by automatic recognition and temporary exclusion (2 min) of ions from which definitive mass spectral data had 
previously been acquired. Moreover, a permanent exclusion list of the most frequent peptide contaminants (keratins and trypsin peptides) was included in the acquisition method in order to focus the analyses of significant data. Mass spectral data obtained from the LC-MS/MS analyses were used to search a nonredundant protein database using an in-house version of the Mascot 2.1 (Matrix Science, Boston, MA, USA) software. Peptide mass values and sequence information from LC-MS/MS experiments were used in the MS/MS lon Search taking into account the Carbamidomethyl-Cys as fixed modification and a precursor ion and a fragment ion mass tolerance of \pm 600 ppm and $0.6 \mathrm{Da}$, respectively.

Statistical Analyses. GraphPad Prism 5 statistical analysis software was used in RT-qPCR performed in this work; in particular, RT-qPCR data were analyzed by $t$ test $(p<0.001)$. The DeCyder Extended Data Analysis Software (denoted as EDA) was used to analyze the DIGE data. The differential expression of proteins between the samples was evaluated by $t$ test. The level of statistical significance was defined as $p<0.01$.

Acknowledgment. The authors gratefully acknowledge S. Shiv Shankar and A. Flagiello for useful discussions, L. Martiradonna for SEM analyses, and V. Fiorelli for the expert technical assistance.

Supporting Information Available: Additional graphical data, images, and tables as described in the text. This material is available free of charge via the Internet at http://pubs.acs.org.

\section{REFERENCES AND NOTES}

1. Kamal, G. D.; Pfaller, M. A.; Rempe, L. E.; Jebson, P. J. Reduced Intravascular Catheter Infection by Antibiotic Bonding. A Prospective, Randomized, Controlled Trial. J. Am. Med. Assoc. 1991, 265, 2364-2368.

2. Klug, D.; Wallet, F.; Kacet, S.; Courcol, R. J. Involvement of Adherence and Adhesion Staphylococcus Epidermidis Genes in Pacemaker Lead-Associated Infections. J. Clin. Microbiol. 2003, 41, 3348-3350.

3. Padera, R. F. Infection in Ventricular Assist Devices: The Role of Biofilm. Cardiovasc. Pathol. 2006, 15, 264-270.

4. Elving, G. J.; van der Mei, H.; Busscher, H.; van Weissenbruch, R.; Albers, F. Influence of Different Combinations of Bacteria and Yeasts in Voice Prosthesis Biofilms on Air Flow Resistance. Antonie van Leeuwenhoek 2003, 83, 45-55.

5. Petrini, P.; Arciola, C. R.; Pezzali, I.; Bozzini, S.; Montanaro, L.; Tanzi, M. C.; Speziale, P.; Visai, L. Antibacterial Activity of Zinc Modified Titanium Oxide Surface. Int. J. Artif. Organs 2006, 29, 434-442.

6. Tunney, M. M.; Dunne, N.; Einarsson, G.; McDowell, A.; Kerr, A.; Patrick, S. Biofilm Formation by Bacteria Isolated from Retrieved Failed Prosthetic Hip Implants in an in Vitro Model of Hip Arthroplasty Antibiotic Prophylaxis. J. Orthop. Res. 2007, 25, 2-10.

7. Costerton, J. W.; Stewart, P. S.; Greenberg, E. P. Bacterial Biofilms: A Common Cause of Persistent Infections. Science 1999, 284, 1318-1322.

8. Hall-Stoodley, L.; Costerton, J. W.; Stoodley, P. Bacterial Biofilms: From the Natural Environment to Infectious Diseases. Nat. Rev. Microbiol. 2004, 2, 95-108.

9. Gristina, A. G. Biomaterial-Centered Infection: Microbial Adhesion versus Tissue Integration. Science 1987, 237, 1588-1595.

10. Mitragotri, S.; Lahann, J. Physical Approaches to Biomaterial Design. Nat. Mater. 2009, 8, 15-23.

11. Verma, A.; Uzun, O.; Hu, Y.; Han, H. S.; Watson, N.; Chen, S.; Irvine, D. J.; Stellacci, F. Surface-Structure-Regulated
Cell-Membrane Penetration by Monolayer-Protected Nanoparticles. Nat. Mater. 2008, 7, 588-595.

12. Dalby, M. J.; Gadegaard, N.; Tare, R.; Andar, A.; Riehle, M. O.; Herzyk, P.; Wilkinson, C. D.; Oreffo, R. O. The Control of Human Mesenchymal Cell Differentiation Using Nanoscale Symmetry and Disorder. Nat. Mater. 2007, 6, 997-1003.

13. Dorobantu, L. S.; Bhattacharjee, S.; Foght, J. M.; Gray, M. R. Analysis of Force Interactions between AFM Tips and Hydrophobic Bacteria Using DLVO Theory. Langmuir 2009, 25, 6968-6976.

14. Mandlik, A.; Swierczynski, A.; Das, A.; Ton-That, H. Pili in Gram-Positive Bacteria: Assembly, Involvement in Colonization and Biofilm Development. Trends Microbiol. 2008, 16, 33-40.

15. O'Toole, G. A.; Kolter, R. Flagellar and Twitching Motility Are Necessary for Pseudomonas aeruginosa Biofilm Development. Mol. Microbiol. 1998, 30, 295-304.

16. Razatos, A.; Ong, Y. L.; Sharma, M. M.; Georgiou, G. Molecular Determinants of Bacterial Adhesion Monitored by Atomic Force Microscopy. Proc. Natl. Acad. Sci. U.S.A. 1998, 95, 11059-11064.

17. Sheng, X.; Ting, Y. P.; Pehkonen, S. O. Force Measurements of Bacterial Adhesion on Metals Using a Cell Probe Atomic Force Microscope. J. Colloid Interface Sci. 2007, 310, 661-669.

18. Liu, Y.; Strauss, J.; Camesano, T. A. Adhesion Forces between Staphylococcus Epidermidis and Surfaces Bearing Self-Assembled Monolayers in the Presence of Model Proteins. Biomaterials 2008, 29, 4374-4382.

19. Ong, Y. L.; Razatos, A.; Georgiou, G.; Sharma, M. M. Adhesion Forces between E. coli Bacteria and Biomaterial Surfaces. Langmuir 1999, 15, 2719-2725.

20. Riedewald, F. Bacterial Adhesion to Surfaces: The Influence of Surface Roughness. PDA J. Pharm. Sci. Technol. 2006, 60, 164-171.

21. Scardino, A. J.; Harvey, E.; De Nys, R. Testing Attachment Point Theory: Diatom Attachment on Microtextured Polyimide Biomimics. Biofouling 2006, 22, 55-60.

22. Shellenberger, K.; Logan, B. E. Effect of Molecular Scale Roughness of Glass Beads on Colloidal and Bacterial Deposition. Environ. Sci. Technol. 2002, 36, 184-189.

23. Mitik-Dineva, N.; Wang, J.; Truong, V. K.; Stoddart, P.; Malherbe, F.; Crawford, R. J.; Ivanova, E. P. Escherichia coli, Pseudomonas aeruginosa, and Staphylococcus aureus Attachment Patterns on Glass Surfaces with Nanoscale Roughness. Curr. Microbiol. 2009, 58, 268-273.

24. Anselme, K.; Davidson, P.; Popa, A. M.; Giazzon, M.; Liley, M.; Ploux, L. The Interaction of Cells and Bacteria with Surfaces Structured at the Nanometre Scale. Acta Biomater. 2010, 6, 3824-3846.

25. Whitehead, K. A.; Colligon, J.; Verran, J. Retention of Microbial Cells in Substratum Surface Features of Micrometer and Submicrometer Dimensions. Colloids Surf., $B$ 2005, 41, 129-138.

26. Diaz, C.; Schilardi, P. L.; Salvarezza, R. C.; de Mele, M. F. Nano/ Microscale Order Affects the Early Stages of Biofilm Formation on Metal Surfaces. Langmuir 2007, 23, 11206-11210.

27. Mitik-Dineva, N.; Wang, J.; Truong, V. K.; Stoddart, P. R.; Malherbe, F.; Crawford, R. J.; Ivanova, E. P. Differences in Colonisation of Five Marine Bacteria on Two Types of Glass Surfaces. Biofouling 2009, 25, 621-631.

28. Popham, D. L.; Young, K. D. Role of Penicillin-Binding Proteins in Bacterial Cell Morphogenesis. Curr. Opin. Microbiol. 2003, 6, 594-599.

29. Thanassi, D. G.; Hultgren, S. J. Multiple Pathways Allow Protein Secretion across the Bacterial Outer Membrane. Curr. Opin. Cell Biol. 2000, 12, 420-430.

30. Jefferson, K. K. What Drives Bacteria to Produce a Biofilm? FEMS Microbiol. Lett. 2004, 236, 163-173.

31. Smyth, C. J.; Marron, M. B.; Twohig, J. M.; Smith, S. G. Fimbrial Adhesins: Similarities and Variations in Structure and Biogenesis. FEMS Immunol. Med. Microbiol. 1996, 16, 127-139.

32. Sun, Y.; Mayers, B.; Xia, Y. Metal Nanostructures with Hollow Interiors. Adv. Mater. 2003, 15, 641-646. 
33. Sun, Y. G.; Xia, Y. N. Mechanistic Study on the Replacement Reaction between Silver Nanostructures and Chloroauric Acid in Aqueous Medium. J. Am. Chem. Soc. 2004, 126, 3892-3901.

34. Bansal, V.; Jani, H.; Du Plessis, J.; Coloe, P. J.; Bhargava, S. K. Galvanic Replacement Reaction on Metal Films: A OneStep Approach to Create Nanoporous Surfaces for Catalysis. Adv. Mater. 2008, 20, 717-723.

35. Rizzello, L.; Shankar, S. S.; Fragouli, D.; Athanassiou, A.; Cingolani, R.; Pompa, P. P. Microscale Patterning of Hydrophobic/Hydrophilic Surfaces by Spatially Controlled Galvanic Displacement Reactions. Langmuir 2009, 25, 60196023.

36. Shankar, S. S.; Rizzello, L.; Cingolani, R.; Rinaldi, R.; Pompa, P. P. Micro/nanoscale Patterning of Nanostructured Metal Substrates for Plasmonic Applications. ACS Nano 2009, 3, 893-900.

37. Brunetti, V.; Maiorano, G.; Rizzello, L.; Sorce, B.; Sabella, S.; Cingolani, R.; Pompa, P. P. Neurons Sense Nanoscale Roughness with Nanometer Sensitivity. Proc. Natl. Acad. Sci. U.S.A. 2010, 107, 6264-6269.

38. Alsteens, D.; Dague, E.; Verbelen, C.; Andre, G.; Dupres, V.; Dufrene, Y. F. Nanoscale Imaging of Microbial Pathogens Using Atomic Force Microscopy. Wiley Interdiscip. Rev.: Nanomed. Nanobiotechnol. 2009, 1, 168-180.

39. Dufrene, Y. F. Using Nanotechniques to Explore Microbial Surfaces. Nat. Rev. Microbiol. 2004, 2, 451-460.

40. Klemm, P. Fimbriae Adhesion, Genetics, Biogenesis, and Vaccines; CRC Press: Boca Raton, FL, 1994.

41. Klemm, P.; Schembri, M. A. Fimbrial Surface Display Systems in Bacteria: From Vaccines to Random Libraries. Microbiology 2000, 146, 3025-3032.

42. Connell, I.; Agace, W.; Klemm, P.; Schembri, M.; Marild, S.; Svanborg, C. Type 1 Fimbrial Expression Enhances Escherichia coli Virulence for the Urinary Tract. Proc. Natl. Acad. Sci. U.S.A. 1996, 93, 9827-9832.

43. Pouttu, R.; Puustinen, T.; Virkola, R.; Hacker, J.; Klemm, P.; Korhonen, T. K. Amino Acid Residue Ala-62 in the FimH Fimbrial Adhesin Is Critical for the Adhesiveness of Meningitis-Associated Escherichia coli to Collagens. Mol. Microbiol. 1999, 31, 1747-1757.

44. Schembri, M. A.; Kjaergaard, K.; Klemm, P. Global Gene Expression in Escherichia coli Biofilms. Mol. Microbiol. 2003, 48, 253-267.

45. Klemm, P.; Vejborg, R. M.; Hancock, V. Prevention of Bacterial Adhesion. Appl. Microbiol. Biotechnol. 2010, 88, 451-459.

46. Adiciptaningrum, A. M.; Blomfield, I. C.; Tans, S. J. Direct Observation of Type 1 Fimbrial Switching. EMBO Rep. 2009, 10, 527-532.

47. Blomfield, I. C. The Regulation of Pap and Type 1 Fimbriation in Escherichia coli. Adv. Microb. Physiol. 2001, 45, 1-49.

48. Blumer, C.; Kleefeld, A.; Lehnen, D.; Heintz, M.; Dobrindt, U.; Nagy, G.; Michaelis, K.; Emody, L.; Polen, T.; Rachel, R.; et al. Regulation of Type 1 Fimbriae Synthesis and Biofilm Formation by the Transcriptional Regulator Lrha of Escherichia coli. Microbiology 2005, 151, 3287-3298.

49. Nishiyama, M.; Ishikawa, T.; Rechsteiner, H.; Glockshuber, R. Reconstitution of Pilus Assembly Reveals a Bacterial Outer Membrane Catalyst. Science 2008, 320, 376-379.

50. Di Michele, M.; Della Corte, A.; Cicchillitti, L.; Del Boccio, P.; Urbani, A.; Ferlini, C.:Scambia, G.; Donati, M. B.; Rotilio, D. A Proteomic Approach to Paclitaxel Chemoresistance in Ovarian Cancer Cell Lines. Biochim. Biophys. Acta 2009, 1794, 225-236.

51. Tumani, H.; Lehmensiek, V.; Lehnert, S.; Otto, M.; Brettschneider, J. 2d Dige of the Cerebrospinal Fluid Proteome in Neurological Diseases. Expert Rev. Proteomics 2010, 7, 29-38.

52. Yang, X.; Liu, J.; He, H.; Zhou, L.; Gong, C.; Wang, X.; Yang, L.; Yuan, J.; Huang, H.; He, L.; Zhang, B.; Zhuang, Z. $\mathrm{SiO}_{2}$ Nanoparticles Induce Cytotoxicity and Protein Expression Alteration in Hacat Cells. Part. Fibre Toxicol. 2010, 7, 1-12.

53. Stephens, A. N.; Pereira-Fantini, P. M.; Wilson, G.; Taylor, R. G.; Rainczuk, A.; Meehan, K. L.; Sourial, M.; Fuller, P. J.;
Stanton, P. G.; Robertson, D. M.; Bines, J. E. Proteomic Analysis of the Intestinal Adaptation Response Reveals Altered Expression of Fatty Acid Binding Proteins Following Massive Small Bowel Resection. J. Proteome Res. 2010, 9, 1437-1449.

54. Rodriguez-Pineiro, A. M.; Blanco-Prieto, S.; Sanchez-Otero, N.; Rodriguez-Berrocal, F. J.; Paez de la Cadena, M. On the Identification of Biomarkers for Non-small Cell Lung Cancer in Serum and Pleural Effusion. J. Proteomics 2010, 73, 1511-1522.

55. Stephens, A. N.; Pereira-Fantini, P. M.; Wilson, G.; Taylor, R. G.; Rainczuk, A.; Meehan, K. L.; Sourial, M.; Fuller, P. J.; Stanton, P. G.; Robertson, D. M.; Bines, J. E. Proteomic Analysis of the Intestinal Adaptation Response Reveals Altered Expression of Fatty Acid Binding Proteins Following Massive Small Bowel Resection. J. Proteome Res. 2009, 9, 1437-1449.

56. Martinez, A.; Kolter, R. Protection of DNA During Oxidative Stress by the Nonspecific DNA-Binding Protein Dps. J. Bacteriol. 1997, 179, 5188-5194.

57. Davalos-Garcia, M.; Conter, A.; Toesca, I.; Gutierrez, C.; Cam, K. Regulation of osmC Gene Expression by the Two-Component System $r \operatorname{cs} B-r c s C$ in Escherichia coli. J. Bacteriol. 2001, 183, 5870587-6.

58. Bouvier, J.; Gordia, S.; Kampmann, G.; Lange, R.; HenggeAronis, R.; Gutierrez, C. Interplay between Global Regulators of Escherichia coli: Effect of RpoS, Lrp and H-NS on Transcription of the Gene osmC. Mol. Microbiol. 1998, 28, 971-980.

59. Wu, T.; Malinverni, J.; Ruiz, N.; Kim, S.; Silhavy, T. J.; Kahne, D. Identification of a Multicomponent Complex Required for Outer Membrane Biogenesis in Escherichia coli. Cell 2005, 121, 235-245.

60. Farnham, P. J.; Greenblatt, J.; Platt, T. Effects of Nusa Protein on Transcription Termination in the Tryptophan Operon of Escherichia coli. Cell 1982, 29, 945-951.

61. Goodell, E. W.; Higgins, C. F. Uptake of Cell Wall Peptides by Salmonella typhimurium and Escherichia coli. J. Bacteriol. 1987, 169, 3861-3865.

62. Koebnik, R.; Locher, K. P.; Van Gelder, P. Structure and Function of Bacterial Outer Membrane Proteins: Barrels in a Nutshell. Mol. Microbiol. 2000, 37, 239-253.

63. Schimmel, P. R.; Soll, D. Aminoacyl-tRNA Synthetases: General Features and Recognition of Transfer RNAs. Annu. Rev. Biochem. 1979, 48, 601-648.

64. Dobson, R. C.; Griffin, M. D.; Roberts, S. J.; Gerrard, J. A. Dihydrodipicolinate Synthase (DHDPS) from Escherichia coli Displays Partial Mixed Inhibition with Respect to Its First Substrate, Pyruvate. Biochimie 2004, 86, 311-315.

65. Andersen, P. S.; Smith, J. M.; Mygind, B. Characterization of the upp Gene Encoding Uracil Phosphoribosyltransferase of Escherichia coli K12. Eur. J. Biochem. 1992, 204, 51-56.

66. Iida, A.; Teshiba, S.; Mizobuchi, K. Identification and Characterization of the $t k t B$ Gene Encoding a Second Transketolase in Escherichia coli K-12. J. Bacteriol. 1993, 175, 5375-5383.

67. Mattevi, A.; Valentini, G.; Rizzi, M.; Speranza, M. L.; Bolognesi, M.; Coda, A. Crystal Structure of Escherichia coli Pyruvate Kinase Type I: Molecular Basis of the Allosteric Transition. Structure 1995, 3, 729-741.

68. Sambrook, J.; Fritsch, E. F.; Maniatis, T. Molecular-Cloning-A Laboratory Manual, 2nd ed.; Cold Spring Harbor Laboratory: Cold Spring Harbor, NY, 1989. 